\title{
Person - job fit and the work commitment of IT Personnel
}

\author{
Therasa $\mathrm{C}^{1}$, Dr. C. Vijayabanu ${ }^{2}$
}

DOI: http://dx.doi.org/10.7322/jhgd.119277

\begin{abstract}
Introduction: There have been given a much higher importance to employee commitment and retention since India is experiencing the highest attrition rate globally Economic Times, $2015^{1}$. Hence, considering the factors of Person-job fit to interpret the impact towards work commitment is very well essential, especially in the current scenario. Work Commitment is a vital element in any organization which has outstanding impact on productivity and functioning and hence it is very much vital to have a committed workforce which is necessary in this competitive environment and tight labour market. In the same way, there is considerable amount of evidence that if $\mathrm{P}-\mathrm{J}$ fit is high then it will have a direct impact on organization commitment also. Person-job fit is the compatibility between person's competency and abilities and the requirements of the job Zheng et al. ${ }^{2}$. If there exists a mismatch between person-job fit then the consequences might result in poor work commitment, low job satisfaction and extremely lower involvement in the job.
\end{abstract}

Objective:This study analyzed the key factors that contribute to Person- job compatibility among IT workers and also analyzed the relationship and impact of Person- job compatibility towards work commitment.

Methods: Exploratory Factor Analysis (EFA) was used to filter the key factors initially, followed by a linear regression technique to determine the impact of Person- job compatibility factors in work commitment on a sample of 300 employees. EFA used Principal Component analysis for extraction and Promax for rotation. Finally regression analysis was carried out to predict the work commitment through statistically significant person-job compatibility variables.

Results: The impact of person-job compatibility on work commitment was studied through regression analysis and it imply that for every unit increase in HR Policy, a 0.52(unstandardised coefficients) increase in work commitment is predicted and it has been turned out as a most impacting variable to predict work commitment. The coefficients for Relationship $(B=.330$, sig $=.000)$, HR Policies $(B=.519$, sig $=.000$ ), Pay and Benefits $(B=.386$, sig $=.000)$ and Employee Growth $(B=.290$, sig $=.001$ ) were statistically significant, since its $p$-value is .000 which is smaller than .05. The coefficients for Work Autonomy (B $=.154$, sig $=.081$ ) was not statistically significant, since its $p$-value is 0.081 which is greater than.05.

Conclusion: The major factors responsible for creating work commitment among IT employees are Relationship, HR Policies and strategies, Pay and benefits, Work autonomy and Employee growth. The most contributing regressors which accounts for creating work commitment are HR policies, Pay and benefits, Employee growth and work autonomy.

Key words: person-job compatibility, work commitment, exploratory factor analysis (EFA), linear regression, perceived compatibility, self-fulfillment, autonomy, job environment factors.

\footnotetext{
1 Research Scholar, School of Management, SASTRA University, Thirumalaisamudrum, Thanjavur, Tamil Nadu, India

2 Associate Professor, School of Management, SASTRA University, Thirumalaisamudrum, Thanjavur, Tamil Nadu, India Corresponding author: Therasa.C. - E-mail: samtheras@gmail.com
}

Suggested citation: Therasa C, Vijayabanu C. Person - job fit and work commitment of it personnel - an indian perspective. J Hum Growth Dev. 26(2): 218-227. Doi: http://dx.doi.org/10.7322/jhgd.119277.

Manuscript submitted: Feb 16 2016, accepted for publication Feb 222016. 


\section{INTRODUCTION}

The fit is actually defined as the employee's "Perceived compatibility or comfort level” with the job, organization, environment, community and culture ${ }^{3}$. The current study emphasizes more on person- job compatibility because specific job factors, namely job knowledge, demands and skills should match job expectations and requirements and the person's competency level.

Person-job compatibility is described as "how compatible an employee is with different work situations and the workplace environment”. Person- job compatibility is how content an individual is with his or her job. It is clearly a person - job fit, which matches the abilities of the person and the demands of the job ${ }^{4}$. Various researchers argued that the person job fit is the key to maintain a committed workforce, especially in a well challenging work environment Bowen et al. ${ }^{5}$, Kristof ${ }^{6}$.

The success of an organization ${ }^{7}$ depends on the appropriate use of manpower which will be an auxiliary to all other assets.Satisfied employees have greater morale, oneness and promote cohesiveness among the members of the organization ${ }^{8}$, which leads to enhanced organizational performance.

Person- job compatibility also refers to the "extent to which workers or job applicants have preferences for job characteristics that are consistent with the actual characteristics of the job" . Person- job compatibility is associated with various factors such as turnover and supervisory ratings of job performance. A study ${ }^{10}$ of concluded that the degree of fit between the employee and job may affect both productivity and work commitment. A meta analysis $^{11}$ explored the relationship between person-job fit, person-organization fit, person-group fit, person-supervisor fit with pre-entry and post-entry level, which includes attitudinal behavior, turnover, performance, strain and occupancy period. This meta-analysis concentrated to find out various ways in which fit was conceptualized and measured, the moderators and its interrelationships between different fits.

The main body of research on Person-/job fit has focused on scrutinizing various relationships it has with other fits and some outcome variables, the current study empirically found out the linear relationship between Person- job compatibility factors and work commitment and also to find out the most important factors which predict the level of work commitment of IT employees. This approach would enable us to evaluate the relative importance of various Person- job compatibility factors which helps in predicting work commitment. Person-job compatibility factors which acts as a predictor variable comprises job factors, self fulfilment factors, job environment factors and independent autonomy factors. The current study used these predictor variables to predict the criterion variable namely the work commitment. Work commitment is an attitude which is a stable and generalized one when compared to job satisfaction which is more dynamic. Carmelite ${ }^{12}$ found that job satisfaction played a mediating role to predict job performance through work commitment. Morrow and Elroy ${ }^{13}$, has studied work commitment which has four measures, including (job involvement, organizational commitment, work ethic endorsement and intention to remain) and job satisfaction of public agency employees.

Workers who have better fit with their work environment generally display greater work satisfaction. They tend to be more committed to their organization and have less intention to leave than employees with poor fit. Disposition based studies have gained renewed interest since performance is a mixture of perception and feelings ${ }^{14}$. The personality of the employee was inevitable in determining the level of job satisfaction when he was equipped with job description ${ }^{15}$. People whose personalities are compatible with their work may demonstrate greater productivity in their work. The employees with a better work environment fit also show less work-related stress and fewer physical symptoms, which could result in lower absenteeism in the organization.

The purpose of this study is to identify the personjob compatibility factors, namely job related factors, selffulfillment factors, autonomy factors and job environment factors and its impact on the work commitment of employees. The basic hypothesis of the study is that the work commitment level can be significantly increased by the person- job compatibility factors. Over the past 20 years, various researches have focused on the retention of employees in the IT environment, Gqubule ${ }^{16}$; Ramakrishna \& Potosky ${ }^{17}$; Van der Merwe ${ }^{18}$. Attrition in IT industry is due to low level of work commitment which is supported by a study which states ${ }^{19}$, that organizations need to focus on how to foster commitment, enhance job satisfaction and to provide support to facilitate employee retention.

The current study aimsto analyze and empirically scrutinize the relationship between job-compatibility factors and work commitment. The objectives isto determine:

1) The existing level of job compatibility factors.

2) The correlation between person-job compatibility factors and work commitment

3) The extent to which person- job compatibility accounts for work commitments.

This study provides a valuable contribution to the existing body of literature and it also conveys a profound understanding of job compatibility factors and its valuable contribution to predict the work commitment level among IT employees. Since IT sector is witnessing higher attrition levels due to several factors like workload, familywork balance and stress the work commitment among employees are in a declining state. The important factors which pack the job compatibility factor will impart great knowledge to HR managers in order to improve the employee outcomes.

\section{METHODS}

This study is based on quantitative survey methods using causal approach. Causal explanatory studies attempt to describe, Cooper \& Schindler ${ }^{20}$, relationships between independent and dependent variables. Statistical surveys in the form of questionnaires are employed in the study to collect primary information from the study sample. A survey, Neuman ${ }^{21}$, was normally an appropriate tool to capture data which are self-reported beliefs or behaviors. 
The data collection period was April-May 2014*. The questionnaires were distributed to 300 employees out of which, 150 are permanent and 150 are seasonal employees from Private Software Company Ltd, Chennai. The study has focused on various person- job compatibility factors such as job related factors, self-fulfillment factors, autonomy factors and job environment factors and also to find out the impact towards work commitment of employees. For the study at hand, factor analysis was deemed appropriate to reduce the number of factors which has been discussed below

The data collected were evaluated by formulating the hypothesis and then by suitable statistical tools the results are portrayed in the following session.

- The association between person- job compatibility factors and work commitment of the employees

- Realizing important person- job compatibility factors which predict work commitment of employees.

- To find out the impact of person-job compatibility factors and work commitment of employees in the organization.

\section{Factors of Person- job compatibility}

Person- job compatibility factors used in this study includes job related factors, self-fulfillment factors, autonomy factors and job environment factors.

\section{Job related factors}

A study by Mataka et al. ${ }^{22}$, used job related factors like supervisor support, co-worker support and access to resources to predict the level of affective commitment. Another study confirmed that the relationship between job security and organizational commitment was found to be most significant, next to that is the work environment which also had a significant relationship with the commitment. Another interesting finding is that pay and participation in decision making do not have a significant relationship with the commitment of employees ${ }^{23}$.

\section{Self- fulfillment factors}

A study by ${ }^{24}$ analyzed career development and employee commitment and found that advancement in career, career counseling and career opportunities to significantly contribute in predicting work commitment of employees.

\section{Autonomy factors}

Job autonomy is defined as "the degree to which the job offers considerable liberty, proving free hand and choice to the individual in scheduling the work and also defining the means to achieve the tasks, Hackman \& Oldham ${ }^{25}$. Naqvi et al. ${ }^{26}$, examined the impact of job autonomy on job satisfaction and organizational commitment with a moderating variable as organizational culture. It revealed a direct relationship with job autonomy and commitment, which mean that increased job autonomy increased the level of both job satisfaction and organizational commitment. Chung ${ }^{27}$ highlighted that autonomy has an influence on work methods, the pace of work and goal directed mindset. Autonomous workers are well versed to decide the means and ends of work ${ }^{28}$.

\section{Job environment factors}

A study of Sandhu \& Ajmal ${ }^{29}$ has taken involvement, coworker cohesion, supervisor support, autonomy, task orientation, work pressure, clarity, managerial control, innovation, physical comfort as the work environment factors. Employee issues Moos \& Billings $^{30}$, employee's health and wellbeing Cooper \& Cartwright ${ }^{31}$, were associated with the work environment. The impact of the work environment has been associated with emotional states of employees and productivity Leka \& Houdmont ${ }^{32}$. Various studies focused on the role of the work environment in determining the employee attitudes and behavior since past two decades $\operatorname{Moos}^{33}$. Hence, in this study, job and working environment factor is included to find the work commitment level of employees.

\section{RESULTS}

\section{Respondents' Demographic Variables}

The demographic variables involved in this study for the 300 respondents are Age, Gender, Education level, Income level and Place of Living. Table 1 illustrates a summary of the respondents' demography.

The table shows the demographic profile of the respondents based on their age, gender, education, income and place of living. Among 300 respondents, $36 \%$ are under 25 years, $35 \%$ belongs to the age group of 26 to 35 years of age, $23 \%$ belongs to the category 36 to 45 years and $6 \%$ belongs to the category 46 to 55 years. Considering the level of education, $12 \%$ of the respondents have completed Diploma/certificate, $46 \%$ of them are UG holders, $40 \%$ of the respondents are PG holders and $2 \%$ of the respondents are professionally qualified. With respect to gender, $46 \%$ of the respondents are male employees and $54 \%$ are female employees. Regarding monthly income $30 \%$ of the samples earned below $3,00,000,47 \%$ of the samples, are categorized under the category $3,00,000-5,00,000,14 \%$ of the samples belong to 5,00,000-7,00,000 categories and $9 \%$ of the samples earned above $7,00,000$. Considering the place of living $20 \%$ of the respondents belongs to rural group, $59 \%$ of the samples belong to the urban group and $21 \%$ of the samples belong to semiurban group.

From the table, 2 it is very much clear that, the overall Cronbach Alpha is (0.888) which reflects the reliability of the data collected and it is also used to test for any inconsistency because of random error. To scrutinize various important Person- job compatibility factors to determine the work commitment level of employees is the main objective of the study. The coefficient of Alpha is greater than (0.6) which shows that the data considered for the study have optimal internal consistency and reliability. From the table it is also clear that the mean scores for Good feeling about the organization (3.95) has been ranked one followed by Responsibility (3.83) and Presence of core value 
Table 1: Profile of respondents $(N=300)$

\begin{tabular}{lcc}
\hline \multicolumn{1}{c}{ Demographic Variables } & Frequency & Percentage (\%) \\
\hline Age & & 36.0 \\
1. 25 and below & 108 & 35.0 \\
2. 26 to 35 & 105 & 23.0 \\
3. 36 to 45 & 69 & 6.0 \\
4. 46 and above & 18 & 45.0 \\
Gender & & 55.0 \\
1. Male & 135 & \\
2. Female & 165 & 12.0 \\
Education & & 46.0 \\
1. Diploma/Certificate & 36 & 40.0 \\
2. UG & 138 & 2.0 \\
3. PG & 120 & \\
4. Professional & 6 & 30.0 \\
Income & & 47.0 \\
1. Below $3,00,000$ & 90 & 14.0 \\
2. 3,00,000 to $5,00,000$ & 141 & 9.0 \\
3. 6,00,000 to $8,00,000$ & 42 & 20.0 \\
4. Above $8,00,000$ & 27 & 59.0 \\
Place of Living & & 21.0 \\
1. Rural & 60 & \\
2. Urban & 177 & \\
3. Semi-Urban & 63 & \\
\hline
\end{tabular}

Table 2: Reliability Analysis and Chi-square Test

\begin{tabular}{|c|c|c|c|c|c|}
\hline Job Factors & Mean & $\begin{array}{l}\text { Standard } \\
\text { Desviaton }\end{array}$ & $\begin{array}{l}\text { Cronbach's } \\
\text { Alpha }\end{array}$ & $\begin{array}{l}\text { Chi-Square } \\
\text { Value }\end{array}$ & Sig. \\
\hline Recognition & 2.73 & 1.000 & .881 & & \\
\hline Work itself & 3.23 & .787 & .886 & & \\
\hline Opportunity for advancement & 3.43 & .984 & .882 & & \\
\hline Professional growth & 3.66 & .829 & .886 & & \\
\hline Responsibility & 3.83 & .982 & .885 & & \\
\hline Good feeling about the organization & 3.95 & .831 & .889 & 2155.263 & .000 \\
\hline Effective senior management & 2.82 & .954 & .880 & & \\
\hline Good relation with co workers. & 3.42 & .852 & .886 & & \\
\hline Effective supervisor & 3.52 & .976 & .880 & & \\
\hline Satisfaction salary with benefits & 3.69 & .881 & .886 & & \\
\hline Presence of core value & 3.82 & 1.054 & .885 & & \\
\hline \multicolumn{6}{|l|}{ Self Fulfilment Factors } \\
\hline Level of pay/salary & 3.21 & 1.024 & .883 & 1299.126 & .000 \\
\hline $\begin{array}{l}\text { The skills level of workers and } \\
\text { supervisors are directly related to job } \\
\text { Company's policies/procedures are }\end{array}$ & 3.52 & .856 & .884 & & \\
\hline comfortable & 3.43 & .932 & .882 & & \\
\hline Opportunity for personal growth & 3.65 & 944 & .886 & & \\
\hline Benefits offered are good & 3.71 & .953 & .885 & & \\
\hline $\begin{array}{l}\text { Opportunity to advance to higher } \\
\text { managerial levels }\end{array}$ & 3.53 & .955 & .889 & & \\
\hline \multicolumn{6}{|l|}{ Autonomy Factors } \\
\hline Respect from by boss & 3.04 & 1.001 & .881 & & \\
\hline Physical work atmosphere is good & 3.42 & 931 & .884 & & \\
\hline Job security in present position & 3.57 & 1.043 & .880 & 862.349 & .000 \\
\hline $\begin{array}{c}\text { Freedom to state mp opinion without fear } \\
\text { of punishment } \\
\text { Job Environment Factors }\end{array}$ & 3.69 & .892 & .889 & & \\
\hline $\begin{array}{l}\text { Working hour requirement of all employees } \\
\text { is comfortable }\end{array}$ & 3.21 & 1.091 & .882 & & \\
\hline Control over daily work activities & 3.58 & .931 & .883 & 747.221 & .000 \\
\hline $\begin{array}{l}\text { Skill level of managerial colleagues is high } \\
\text { Overall Cronbach Alpha } \\
(0.888)\end{array}$ & 3.49 & 1.017 & .882 & & \\
\hline
\end{tabular}


(3.82) occupied the third rank among various Personjob compatibility factors used for the study.

Research question \#1: Whether there is a significant association between the person -job fit factors and work commitment?

The use of chi-square, test the association between Person- job compatibility factors and the level of work commitment is analyzed by formulating the hypothesis.

H1: Person- job compatibility factors are associated with the work commitment level of employees in the organization.

From table 2, it can be seen that the chi square value is significant for all the Person- job compatibility factors, namely Job factors (2155.263), Self Fulfillment factors (1299.126), Autonomy factors (862.349) and job environment factors (747.221) and since its p-value ( $p=0.000$ ) is less than 0.001 null hypothesis is rejected and alternate hypothesis is accepted. Hence it is concluded that there exists an association between Person- job compatibility factors and the level of work commitment among employees in the organization.

Research questions \#2: What are the most decisive factors of Person- job compatibility?

At table.3 KMO and Bartlett's test of sphericity produces the Kaiser-Meyer-Olkin measure of sampling adequacy and Bartlett's test Field ${ }^{34}$. The value of KMO should

Table 3: Factor analysis for the factors included in the Person- job compatibility

\section{KMO and Bartlett's Test}

Kaiser-Meyer-Olkin Measure of Sampling Adequacy.

Bartlett's Test of Sphericity
.823

$\begin{array}{cc}\text { Approx. Chi-Square } & 2000.519 \\ \text { Df } & 153 \\ \text { Sig. } & .000\end{array}$

be greater than 0.5 if the sample is adequate. The KaiserMeyer-Olkin Measure of Sampling adequacy is 823, which shows that sample for this study is quite adequate.

From the table.4, it was clear that exploratory factor analysis extracted five factors, which accounted for $62.882 \%$ of variance in the data. The communalities of 16 items ranged from 0.504 to 0.807 indicating that a large amount of variance has been extracted from the factor solution. The five factors are named as follows. F1- 'Relationship' (Effective senior management, Good relation with co workers and Recognition), F2 - 'HR Policies' (Company's policies/procedures are comfortable, Level of pay/salary and Working hour requirement of all employees is comfortable), F3 - 'Pay and Benefits'(Presence of core value, Satisfaction salary with benefits, Good feeling about the organization and Effective supervisor), F4 - 'Work Autonomy'(Freedom to state mp opinion without fear of punishment, Physical work atmosphere is good and Responsibility) and F5 - 'Employee Growth'(Opportunity to advance to higher managerial levels, Benefits offered are good and Opportunity for personal growth). The first factor (F1 - Relationship) contains three components with high factor loadings which is above 0.80 and explains most of the

Table 4: Promax rotated Factor Loading Matrix

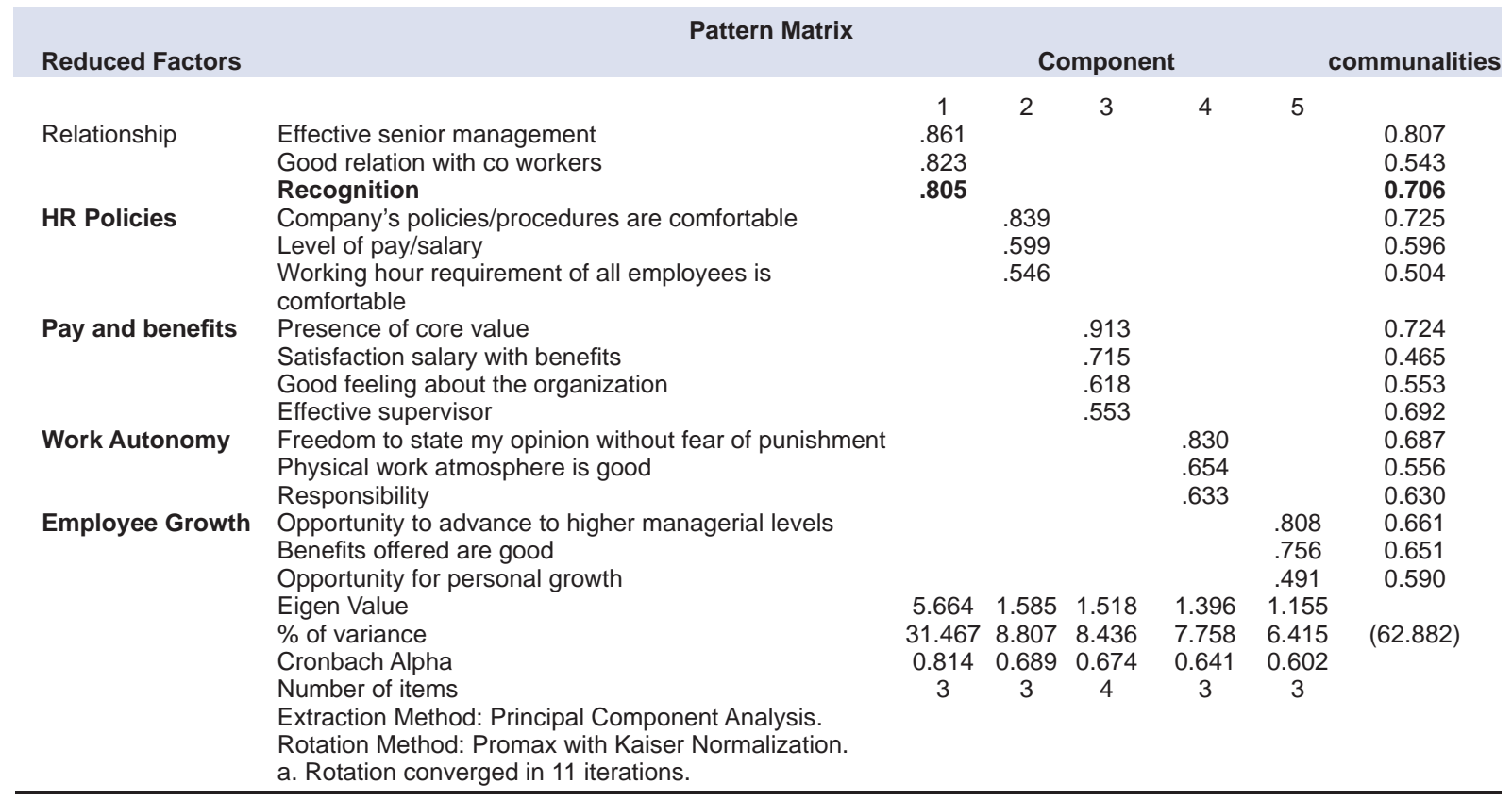


variance which is $31.467 \%$ is considered an important determinant for predicting work commitment levels of employees in the organization.

The results of the reliability analysis showed that Cronbach's alpha coefficients of the extracted factors ranged from 0.814 to 0.602 . That is well above the minimum value of 0.60 , which is considered acceptable as an indication of scale reliability Hair et al. ${ }^{35}$. Thus, these values suggest good internal consistency of the factors. Finally, Cronbach's alpha value for the overall Person- job compatibility scale is 0.888 and indicates its high reliability.

\section{Correlation analysis}

Correlation analysis was used to determine the correlation of each Person- job compatibility factors extracted from the factor analysis of work commitment at the 0.05 level of significance. It has highlighted the fact that there is a significant positive correlation between the Person- job compatibility factors extracted from the factor analysis and the overall work commitment level.

Research question \#3: What is the impact of Person- job compatibility factors on Work Commitment?

Multiple Regression analysis: Person- job compatibility Factors and Work commitment (WC) $(\mathrm{N}=300)$

To answer the research question 3, regression analysis was carried out to find the impact of independent variables on a dependent variable. All the hypothesized relation was found to be significant which is presented in table.6.

The multi-collinearity was not a problem as none of the correlation value between predictor variables in the

Table 5: The Pearson Correlation analysis between Person- job compatibility factors and Work commitment $(\mathrm{N}=300)$

\begin{tabular}{|c|c|c|c|c|c|c|}
\hline Factors & Work Commitment & Relationship & HR Policies & Pay \& Benefits & Work autonomy & Employee growth \\
\hline WorkCommitment & 1 & & & & & \\
\hline Relationship & $.184^{\star \star}$ & 1 & & & & \\
\hline HR Policies & $.423^{\star \star}$ & $.529 * \star$ & 1 & & & \\
\hline Pay\&Benefits & $.399 * *$ & $.431^{\star *}$ & $.335^{\star *}$ & 1 & & \\
\hline Work autonomy & $.249 * \star$ & $.350 * \star$ & $.361^{\star *}$ & $.245^{\star \star}$ & 1 & \\
\hline Employee growth & $.307^{* *}$ & $.343^{\star *}$ & $.275^{\star \star}$ & $.309 * *$ & $.181^{* *}$ & 1 \\
\hline
\end{tabular}

** Correlation is significant at the 0.01 level (2-tailed).

table. 5 was above 0.6 Padhazur ${ }^{36}$, Chiu et al. ${ }^{37}$. In the regression analysis, all the factors of Person- job compatibility are significantly influencing work commitment of employees.

In table $6, \mathrm{R}$ value represents the simple correlation. The correlation value indicates a quite high degree of correlation between Person- job compatibility and work commitment $(r=0.555)$. The R2 column indicates how much of the total variation in the dependent variable (work commitment) can be explained by the independent variable (Person- job compatibility factors) and here it is (R2 $=30.8 \%$ ) can be explained by Person- job compatibility factors which is quite a good influence. Four factors of Person- job compatibility Relationship, HR Policies, Pay and benefits and Employee growth towards work commitment have been explained in the model with much more statistical significance.
So it is concluded that the regression model is statistically, significantly predicting the outcome of work commitment through Person-job compatibility factors which conclude a good fit for the data too.

Beta coefficients for the regression model provide necessary information to predict the level of work commitment from various Person- job compatibility factors. In the regression model in table.7, HR Policies $(\mathrm{B}=0.362$, Sig. $<.001)$ and Pay and Benefits $(\mathrm{B}=0.300$, Sig.<.001) are contributing the maximum to predict work commitment of employees. It is followed by Relationship ( $\mathrm{B}=-.230$, Sig. <.001) which is a negative value, and concludes that a one unit change in the relationship factor is expected to result in a -2 standard deviation change in work commitment.

Table 6: Model Summary for regression analysis

\begin{tabular}{ccccccc}
$\begin{array}{c}\text { Dependent } \\
\text { Variable }\end{array}$ & $\begin{array}{c}\text { Independent variables } \\
\text { (Person- job } \\
\text { compatibility factors) }\end{array}$ & $\mathbf{R}$ & $\mathbf{R}^{2}$ & $\begin{array}{c}\text { Std. } \\
\text { Error of } \\
\text { estimate }\end{array}$ & F & Sig. \\
& F1-Relationship & .184 & 0.034 & 3.38 & 10.440 & .001 \\
Work & F2-HR Policies & .423 & .179 & 3.12 & 64.828 & .000 \\
commitment & F3-Pay \& Benefits & .399 & .160 & 3.16 & 56.580 & .000 \\
& F4-Work Autonomy & .249 & .062 & 3.34 & 19.674 & .000 \\
& F5-Employee Growth & .307 & .094 & 3.28 & 30.963 & .000 \\
& $\begin{array}{c}\text { Person- job } \\
\text { compatibility Factors }\end{array}$ & $\mathbf{. 5 5 5}$ & $\mathbf{3 0 8}$ & $\mathbf{2 . 8 8}$ & $\mathbf{2 6 . 1 6 5}$ & $\mathbf{0 0 0}$ \\
\hline
\end{tabular}


Table 7: Work commitment regressed on person-job compatibility factors

\begin{tabular}{|c|c|c|c|c|c|c|}
\hline \multirow[t]{2}{*}{ Variable } & \multirow[t]{2}{*}{ Regressors } & \multicolumn{2}{|c|}{$\begin{array}{l}\text { Coefficients }^{\mathrm{a}} \\
\text { Unstandardized } \\
\text { Coefficients }\end{array}$} & \multirow{2}{*}{$\begin{array}{c}\text { Standardized } \\
\text { Coefficients } \\
\text { Beta }\end{array}$} & \multirow[t]{2}{*}{$\mathbf{T}$} & \multirow[t]{2}{*}{ Sig. } \\
\hline & & B & Std. error & & & \\
\hline \multirow{6}{*}{$\begin{array}{c}\text { Work } \\
\text { commitment }\end{array}$} & (Constant) & 12.676 & 1.292 & & 9.814 & .000 \\
\hline & Relationship & -.330 & .089 & -.230 & -3.708 & .000 \\
\hline & HR Policies & .519 & .085 & .362 & 6.104 & .000 \\
\hline & Pay\&Benefits & .386 & .071 & .300 & 5.428 & .000 \\
\hline & Work Autonomy & .154 & .088 & .093 & 1.748 & .081 \\
\hline & Employee growth & .293 & .088 & .177 & 3.344 & .001 \\
\hline
\end{tabular}

The regression model fit is, Work Commitment $(\mathrm{Y})=12.676$ - Relationship (0.330) + HR Policies (0.519) + Pay \& Benefits (0.386) + Work Autonomy $(0.154)+$ Employee Growth (0.293).

\section{DISCUSSION}

Even though the person-job fit has been widely researched their influence on job performance and various other organizational outcome variables is still limited Mosley $^{38}$. The person- job compatibility which is nothing but the person-job fit and it is gaining more attention in recent years. The Person- job compatibility arises when a match between knowledge, skills and abilities of the individual and job requirements exists and also the desires or needs of the employee have been met by the job which is simply called as needs-supplies perspective and demands-abilities perspective Edwards ${ }^{39}$. The person - job fit is treated as the traditional foundation for employee selection ${ }^{40}$.

The determination of Person- job compatibility factors and their impact on work commitment plays a vital role. In this research study, an Exploratory Factor Analysis (EFA) was accustomed in order to identify and extract five major factors of Person- job compatibility for IT employees. The EFA analysis identified five major factors namely Relationship, HR Policies, Pay and Benefits, Work autonomy and Employee growth.

The findings of this study reveal that among the five dimensions 'Relationship' which is factor 1 has emerged as the most important predictor of work commitment. In the IT industry, this dimension refers to having good relationships with the co-workers, recognizing each other in a team and having a superior supportive relationship. This finding is supported by Lumbley et al. ${ }^{41}$, who conducted his research in IT industry and another author Woo \& Chelladurai ${ }^{42}$ has also supported that employee's perception of support available at work developing a sense of commitment but in a different work setting. Managers of IT organizations play an important role to formulate HR Policies to fit an employee to a role which best suits his/her qualification. The important factors that could be packed with person-job fit should be done, which always boost up the work commitment level among IT employees. The appeal towards person-job fit has long been a research focus in organizational behavior Chuang ${ }^{43}$.
A study by Heshmat ${ }^{44}$ found out some important factors contributing to employee performance, which includes job satisfaction, individual career growth, updated technology and tenure of employment and the factors that appeared to be least related to optimum employee performance were health experiences, environmental conditions and muscular activities. The fit between the individual and the job was related to various attitudinal and behavioral outcomes such as job satisfaction, work commitment, turnover intention and performance Hoffman \& Woehr ${ }^{45}$; Kristof-Brown et al. ${ }^{11}$; Verquer et al. ${ }^{46}$.

Several literatures affirmed that, the employees who are highly committed will go along with their organizations' goals and values and will get engaged to the organization and take extra effort to grow along with the organization Steers ${ }^{47}$; Panaccio \& Vandenberghe ${ }^{48}$. Various fits namely person-organization fit, person-job fit and person-environment fit should be constantly high for the employee to develop a strong affinity towards the organization. Those who have a better fit with the job environment may work more comfortably in their organizations than those who have a poorer fit with their job environment. Person-environment fit is an important topic in industrial and organizational psychology because of its apparent influence on attitudes and performance among personnel in the workplace.

Job autonomy increases job performance Saragih ${ }^{49}$, because it makes an employee feel that they are skillful and creative in completing their jobs in an efficient manner. If individuals to be successful, they must use the knowledge required to perform a specific job and they must also acquire autonomy to make wise decisions to perform the work successfully ${ }^{50}$.

\section{CONCLUSION}

We concluded that the major factors which are responsible for creating a work commitment among employees are Relationship, HR Policies and strategies, Pay and benefits, Work autonomy and Employee growth. Regarding job factors, the most suggested statement by the employees is, "Good feeling about the organization" which has the greatest mean value and it implies that employees are feeling that a good feel about the organization will create a work commitment among them. This is 
followed by "Presence of core value". This indicates that an organization with the strong core value definitely creates a strong, loyal and committed workforce. The most contributing covariates which accounts for creating work commitment are HR policies, Pay and benefits, Employee growth and work autonomy.

\section{ACKNOWLEDGEMENTS*}

I express my gratitude to G. Karthikeyan, MBA Student who has been instrumental in data collection for the project.

\section{REFERENCES}

1. The Economic Times. Jobs. . [cited 2016 Mar 05] Available from: http://articles.economictimes.indiatimes. com/2015-02-08/news/58928662_1_attrition-level-sectors-psu-jobs.

2. Zheng W, Kaur S, Zhi T. A critical review of employee turnover model (1938-2009) and development in perspective of performance. African J Bus Manag. 2010;4(19), 4146-58.

3. Mitchell TR, Holtom BC, Lee TW, Sablynski CJ, Erez M. Why People Stay: Using Job embeddedness to predict voluntary turnover. Acad Manag J. 2001;44: 1102-22. DOI: http://dx.doi.org/10.2307/3069391

4. Sekiguchi T. Person-organization fit and person-job fit in employee selection: a review of the literature. J Osaka Keidai Ronshu. 2004;54(6):179-96.

5. Bowen DE, Ledford GE, Nathan BR. Hiring for the organisation, not the job. Acad Manag Executive. 1991;5(4):35-51.

6. Kristof AL. Person-organisation fit: an integrative review of its conceptualizations, measurement, and implications.Pers Psychol. 1996;49(1):1-49. DOI: http://dx.doi.org/10.1111/j.1744-6570.1996.tb01790.x

7. Vijayabanu C, Amudha R. A study on efficacy of employee training: review of literature. Bus Theory Pract. 2012;13(3):275-82. DOI: http://dx.doi.org/10.3846/btp.2012.29

8. Vijayabanu C, Amudha R, Surulivel ST. A study on efficacy of induction training programme in Indian Railways using factor analysis. Bus Theory Pract. 2013;14(2):140-6. DOI: http://dx.doi.org/10.3846/ btp.2013.15

9. Bernardin HJ. Innovative approaches to personnel selection and performance appraisal. J Manag Sys. 1989; 1:25-36.

10. Rousseau DM, Parks JM. The contracts of individuals and organisations. Res Organisat Behav. 1992;15:1-43.

11. Kristof-Brown AL, Zimmerman RD, Johnson EC. Consequences of individuals' fitat work: a meta-analysis of person-job, person-organization, person-group, and person-supervisor fit. Pers Psychol. 2005;58(2):281-342.

12. Washington Post Staff Writer. Carmelites, Outdated but Still Fervent. 2004. [cited 2016 Jun 21] Available from: http://www.washingtonpost.com/wp-dyn/articles/A33190-2004Aug1.html

13. Morrow P, McElroy J. Efficiency as a mediator in turnover - organizational performance relations. 2007;6096): 827-49.

14. Therasa C, Vijayabanu C. The impact of big five personality traits and positive psychological strengths towards job satisfaction: a review. Period Polytech Soc Man Sci. 2015;23(2):142-50. DOI: http://dx.doi. org/10.3311/PPso.7620

15. Vijayabanu C, Therasa C. Training based on sequential need analysis process in a public sector organization. Int J Ind Engineering Manag. 2014;5(3):139-50.

16. Gqubule T. The real retainer. Financial Mail. 2006;187(1):1.

17. Ramakrishna HV, Potosky D. Structural shifts in career anchors of information systems personnel: A preliminary empirical analysis. J Comp Informat Sys. 2002;42(2):83-9. DOI: http://dx.doi.org/10.1080/08874 417.2002.11647491

18. Van der Merwe W. Determining employees' perceptions of non-financial recognition initiatives. Unpublished masters dissertation, University of Pretoria. Pretoria: 2008.

19. Rekha KRS, Kamalanabhan TJ. A study on the employee turnover antecedents in ITES/BPO sector. Int J Learning Change. 2010;4(2):164-80. DOI: http://dx.doi.org/10.1504/IJLC.2010.032710

20. Cooper DR, Schindler PS. Business research methods. 12th Edition. McGraw-Hill Education; 2013.

21. Neuman WL. Social research methods: qualitative and quantitative approaches. Allyn and Bacon; 2003.

22. Mataka K,Elegwa M, Maurice S. Job-Related Factors and their Influence on Organizational Commitment of PartTime Academic Staff in Institutions of Higher Education in Nairobi and Mombasa Cities in Kenya. Int J Bus Social Sci. 2014;5(8):110-119.

23. Abdullah, Ramay MI. Antecedents of Organizational Commitment of Banking Sector Employees in Pakistan. Serbian J Manag. 2011;7(1):89-102. DOI: http://dx.doi.org/10.5937/sjm1201089A

24. Ogaboh AAM, Nkpoyen F, Ushle EM. Career development and employee commitment in industrial organisations in Calabar, Nigeria. Am J Scient Ind Res. 2010;1(2):105-114. DOI: http://dx.doi.org/10.5251/ ajsir.2010.1.2.105.114

25. Hackman JR, Oldham GR. Development of the job diagnostic survey. J Appl Psychol. 1975;60(2): 159-70. http://dx.doi.org/10.1037/h0076546 
26. Naqvi SMMR, Ishtiaq M, Kanwal N, Ali M . Impact of Job Autonomy on Organizational Commitment and Job Satisfaction: The Moderating Role of Organizational Culture in Fast Food Sector of Pakistan. Int J Bus Manag. 2013;8(17):92-102. DOI: http://dx.doi.org/10.5539/ijbm.v8n17p92

27. Chung K. Motivational theories and practices. Columbus: Grid Publishing; 1977.

28. Nicholson N. A theory of work role transitions. Adm Sci Quarterly. 1984;29(2):172-91. DOI: http://dx.doi. org/10.2307/2393172

29. M Sandhu, M Ajmal. The adoption of ICT in project-based and traditional organizations: evidence from Finnish and Swedish companies. J Enterprise Informat Manag. 2012;25(1):7-27. DOI: http://dx.doi. org/10.1108/17410391211192143

30. Moos RH, Billings A. Understanding and improving work climates. In: Jones JW, Steffy BD, Bray DW. Applying psychology in business: The handbook for managers and human resource professionals. Lexington: Lexington Books; 1991; p.552-62.

31. Cooper CL, Cartwright S. Healthy mind, healthy organisation: a proactive approach to occupational stress. Human Relations. 1994;47: 455-470.

32. Leka S, Houdmont J. Occupational Health Psychology. Wiley-Blackwell; 2010.

33. Moos RH, Moos BS. Family Environment Scale Manual. 3rd. Palo Alto: Consulting Psychologists Press; 1994.

34. Field AP. Discovering statistics using SPSS. $2^{\text {nd }}$ edition. London: Sage. 2005.

35. Hair J, Black W, Babin B, Anderson R, Tatham R. Multivariate data analysis 6th ed. Uppersaddle River: Pearson Prentice Hall. 2006.

36. Pedhazur EJ. Book Review : multiple regression in behavioral research. 2nd ed. New York: 1982; p.822.

37. Chiu RK, Man JSW, Thayer. Effects of role conflict on stress of three professions in Hong Kong: a path analysis approach. J Manag Psychol. 1998;13(5-6):318-33. DOI: http://dx.doi.org/10.1108/02683949810219882

38. Mosley DC. The influence of person-job fit, person-organisation fit, and self-efficacy perceptions on work attitudes, job performance and turnover. (Doctoral dissertation). Mississippi State University. Department of Management and Information Systems. 2002.39. Edwards JR. Person-Job Fit: a conceptual integration, Literature review and methodological critique. In: Cooper CL, Robertson IT. International review of industrial and organizational psychology. Vol.6. New York: Wiley; 1991; p.283-357.

40. Werbel JD, Gilliland SW. Person-environment fit in the selection process. In: Ferris GR. Research in personnel and human resource management. Stamford: JAI Press; 1999; p.209-43.

41. Lumley MA, Cohen JL, Borszcz GS, Cano A, Radcliffe AM, Porter LS, et al. Pain and emotion: a biopsychosocial review of recent research. J Clin Psychol. 2011;67(9):942-68. DOI: http://dx.doi.org/10.1002/ jclp.20816

42. Woo B, Chelladurai P. Dynamics of perceived support and work attitudes: the case of fitness club employees. Hum Res Manag Res. 2012;2(1):6-18. DOI: http://dx.doi.org/10.5923/j.hrmr.20120201.02

43. Chuang A, Sackett PR. (2005). The Perceived Importance of person-job fit and person-organisation fit between and within interview stages. Soc Behav Personality. 2005;33(3):209-26. DOI: http://dx.doi. org/10.2224/sbp.2005.33.3.209

44. Heshmat AS. A Case study of work compatibility factors in an education provider in Egypt. University Of Louisville; 2008.

45. Hoffman BJ, Woehr DJ. A quantitative review of the relationship betweenperson - organization fit and behavioural outcomes. J Vocational Behav. 2006;68(3):389-99. DOI: http://dx.doi.org/10.1016/j. jvb.2005.08.003

46. Verquer ML, Beehr TA, Wagner SH. A Meta-analysis of relations betweenperson-organization fit and work attitudes. J Vocational Behav. 2003;63(3):473-89.

47. Steers RM. Antecedents and outcomes of organizational commitment. Adm Sci Quarterly. 1977;22(1):4656. DOI: http://dx.doi.org/10.2307/2391745

48. Panaccio A, Vandenberghe C. Perceived organizational support, organizational commitment and psychological well-being: a longitudinal study. J Vocational Behav. 2009;75:224-36. DOI: http://dx.doi. org/10.1016/j.jvb.2009.06.002

49. Saragih S. The Effects of Job Autonomy on Work Outcomes: Self Efficacy as an Intervening Variable. Int Res J Bus Studies. 2011;4(3):203-15.

50. Öztürk $\mathrm{IH}$. Curriculum reform and teacher autonomy in Turkey: The case of the history teaching. Int $\mathrm{J}$ Instruction. 2011;4(2):113-28. 
This article is distributed under the terms of the Creative Commons Attribution 4.0 International License (http://creativecommons.org/licenses/by/4.0/), which permits unrestricted use, distribution, and reproduction in any medium, provided you give appropriate credit to the original author(s) and the source, provide a link to the Creative Commons license, and indicate if changes were made. The Creative Commons Public Domain Dedication waiver (http://creativecommons.org/publicdomain/zero/1.0/) applies to the data made available in this article, unless otherwise stated.

\section{Resumo}

Introdução: Tem sido dada uma importância muito maior à participação dos trabalhadores e retenção desde que a Índia está enfrentando a maior taxa de atrito globalmente Economic Times, 2015‥ Assim, considerando os fatores de Pessoa - job apto a interpretar o impacto no compromisso de trabalho é muito bem essencial, especialmente no Compromisso scenario.Work atual é um elemento vital de qualquer constituição que tem um impacto notável na produtividade e funcionamento . Mas, quando os funcionários vão sentir o compromisso de trabalho é o futuro pergunta. Existe uma forte relação entre ajuste pessoa - trabalho e compromisso de trabalho . ajuste pessoa - trabalho é a compatibilidade entre competência e habilidades da pessoa e as exigências do trabalho Zheng et al. ${ }^{2}$. Se existe uma incompatibilidade entre o ajuste pessoa - trabalho, então as consequências podem resultar em compromisso de trabalho pobre, baixa satisfação no trabalho e extremamente menor envolvimento no trabalho.

Objetivo: Este estudo analisou os principais fatores que contribuem para a pessoa- a compatibilidade de trabalho entre TI trabalhadores e também analisou a relação eo impacto da compatibilidade de trabalho Person- no compromisso de trabalho.

Método: Exploratory Factor de Analysis (EFA) foi usado para filtrar os fatores-chave inicialmente, seguido por uma técnica de regressão linear para determinar o impacto da pessoa- fatores de compatibilidade emprego no compromisso de trabalho em uma amostra de 300 empregados. EFA utilizada análise de componentes principais para a extração e Promax para rotação . Finalmente a análise de regressão foi realizada para prever o compromisso de trabalho por meio de variáveis estatisticamente significativas de compatibilidade pessoa - trabalho.

Resultados: Os resultados revelaram os principais fatores que determinam o nível de compromisso de trabalho são condições de RH, remuneração e benefícios e relacionamento entre os colegas de trabalho.

Conclusão: Os principais fatores que são responsáveis pela criação de compromisso de trabalho entre empregados são Relacionamento, Políticas e estratégias de $\mathrm{RH}$, remuneração e benefícios, o trabalho autonomia e crescimento do empregado. Os regride mais contribuem que representa a criação de compromisso de trabalho são as políticas de $\mathrm{RH}$, remuneração e benefícios, o crescimento do empregado e trabalhar autonomia. O impacto da compatibilidade pessoa-trabalho no compromisso de trabalho foi estudada através de análise de regressão e isso implica que para cada aumento de uma unidade na política de $\mathrm{RH}$, a 0,52 (coeficientes unstandardised) aumento no compromisso de trabalho está previsto e foi acabou como uma variável de maior impacto para prever compromisso de trabalho. Os coeficientes para Relacionamento $(B=0,330, s i g=0,000)$, Políticas de Recursos Humanos $(B=0,519$, sig $=0,000)$, remuneração e benefícios $(B=0,386$, sig $=0,000)$ e Crescimento Empregado $(B=0,290$, sig $=0,001)$ foram significativamente diferente de 0 , desde o seu valor de $p$ era 0,000 que é menor do que 0,05 . Os coeficientes para o Trabalho Autonomia ( $B=0,154, S O G=0,081$ ) não foi estatisticamente diferente de zero, porque o seu valor-p é 0,081 , que é maior do que 0,05 . A implicação desta pesquisa vai ajudar os gestores a criar um ambiente de trabalho bem compatível concentrandose em importantes construções de compatibilidade trabalho pessoa- que têm um possível efeito positivo no compromisso de trabalho e reduzindo, assim, a intenção de rotatividade dos empregados. Ainda mais aumentou compromisso de trabalho resultará em resultados do trabalho positivos, tais como a satisfação no trabalho e comprometimento organizacional.

Palavras-chave: compatibilidade de trabalho Person; compromisso de trabalho; análise fatorial exploratória (EFA); regressão linear; compatibilidade percebida; auto-realização; a autonomia; fatores de ambiente de trabalho. 